\title{
IAMJ
}

INTERNATIONAL

AYURVEDIC

MEDICAL JOURNAL

\section{A CLINICAL STUDY TO EVALUATE THE IMPACT OF VAMANA KARMA ON SERUM ELECTROLYTES IN AMAVATA W.S.R RHEUEMATOID ARTHRITIS}

\author{
Rakshitha Kumari ${ }^{1}$, Niranjan Rao $^{2}$ \\ ${ }^{1}$ M.D Scholar, ${ }^{2}$ Professor and HOD \\ Department of PG Studies in Panchakarma, Shree Dharmasthala Manjunatheshwar College of \\ Ayurveda Udupi, Karnataka, India
}

Corresponding Author: kulalrakshitha5@gmail.com

https://doi.org/10.46607/iamj04p5042021

(Published online: May 2021)

Open Access

(C) International Ayurvedic Medical Journal, India 2021

Article Received: 15/05/2021 - Peer Reviewed: 20/05/2021 - Accepted for Publication: 22/05/2021

Check for updates

\begin{abstract}
Panchakarma therapy is the ideal line of treatment to maintain the state of health for a longer duration. It aims at the elimination of excessive Doshas from the body. Vamana karma is one of the Panchakarma procedure where in vomiting is induced by drugs and aims at the elimination of excessive Kapha and Pitta dosha from the body. Amavata is a Vyadhi where Kapha and Vata are predominantly involved. Its Udhbava Sthana is Amashaya and Vyaktha Sthana is Sandhi. Vamana is considered as best treatment for Kapha and its associated conditions. In Amavata mainly Kapha Sthana like Sandhi is affected. Langhana is considered as the prime line of treatment for Amavata. Vamana is considered under shodhana variety of Langhana. Normally, after Vamana patient does not complain of having any untowards like those patients after vomiting due to dehydration. This study was conducted to evaluate the effect of vamana karma on serum electrolyte levels and access the safety of therapeutic vomiting.

In this study, 20 patients diagnosed with Amavata were selected and subjected for Vamana karma. This study involves estimation of serum electrolyte levels before and after Vamana. The results are suggestive of safe application of the Vamana karma.
\end{abstract}


Keywords: Amavata, Serum electrolytes, Vamana karma.

\section{INTRODUCTION}

Generally, any measure of Shodhana therapy cannot be undertaken directly without preparing the patient. Vamana is somewhat strainful process to the patient and may cause complications also if not performed properly. Therefore, it is necessary that all the aspects should be taken into consideration before performing this karma. Shodhana therapy is generally applied mostly in chronic disease where vitiated doshas are at higher level and where Shamana drugs may not have significant role. In this situation we have to take care at every step of treatment and procedure. Some process should be done before treatment as Poorva karma and some are after treatment as Paschat karma. Vamaka Dravya acts on stomach at very root cause of Kapha vitiation. It eliminates the Kleda, open srotas and pacify Ama thus offer significant relief in Kapha. Thus, Vamana karma relieves symptoms of Amavata. Amavata is a Vyadhi having Bahudoshavastha, where Tridosha are predominantly involved. In the presence of Bahudoshavastha ${ }^{\{1\}}$ and Ama in Amashaya, Shodhana karma is the prime line of treatment. The Doshas are eliminated from nearer route hence, $\mathrm{Va}$ mana is planned. This Vamana is practiced as Sadyo vamana where the Ama with Dosha are eliminated from Amashaya and the Agni is normalized. In Amashayotta vyadhis and in Rasapradoshaja vyadhis, Langhana is the first line of treatment. This Langhana is in the form of Upavasa in the initial stage of the disease when the Agni and Rasa Dhatu are involved with Alpa Dosha. Vamana Karma is the Shodhana roopi langhana indicated to person suffer from diseases due to abundance Kapha and Pitta, Raktha and Mala combined with the vitiation of Vata, it brings the lightness in the body by eliminating the Dosha ${ }^{\{2\}}$. The active principles of Vamana Dravyas are absorbed from the stomach into circulatory system, where from it circulated to all over the body. On reaching at the site of lesion, which is at the cellular level, it breaks the nexus of doshas and brings back the toxic substances. Thus, released into stomach and expelled out by forceful expulsion. ${ }^{\{3\}}$
If patient suffering from vomiting, then certainly there is loss of electrolytes from the body resulting in weakness, development of cramps due to dehydration. However, if vomiting is induced through Vamana karma and if Samyak Shudhi occurs, no such symptoms occur. The assessment of Vamana karma is based on various parameter termed as Shuddhi criteria like Vegiki, Maniki, Laingiki and Anthiki shuddhi. The Doshas are eliminated are classified on the basis of number of bouts of evacuation as Pravara, Madhyama, Avara Shuddhi. These are 8,6,4 times respectively. After vomiting in such high numbers, if there is an electrolyte imbalance, it needs to be evaluated and the levels are to be compared before and after Vamana karma.

\section{Aim and Objectives:}

The present study was aimed to ascertain the safety of Vamana karma and evaluate the serum electrolytes levels before and after Vamana karma.

\section{Materials and Methods:}

Source of the Data:- Minimum of 20 patients diagnosed as Amavata is taken from IPD/OPD of Shri Dharmasthala Manjunatheswara Ayurveda Hospital, Udupi.

\section{Method of collection of the data: -}

\section{Study design:}

- This is an open label clinical study with pre-test and post-test design where in minimum 20 patients diagnosed of Rheumatoid Arthritis of either gender will be selected based on diagnostic and inclusion criteria.

Sample size: Minimum 20 patients diagnosed of Rheumatoid Arthritis will be selected.

- A detailed proforma will be prepared considering the points pertaining to signs, symptoms and examinations as mentioned in Ayurvedic classics and allied sciences to confirm the diagnosis. 


\section{Interventions:}

\section{Poorva Karma:}

- Pachana \& Deepana-Chitrakadi Vati ${ }^{[4\}} 400 \mathrm{mg} 2$ tablets tid, before food- 3 to 7 days with Ushnodaka as Anupana till the occurrence of Niramavasta.

- Snehapana-Moorchitha Gritha ${ }^{\{5\}}$ for 3 to 7 days in Arohana Krama till the achievements of Samyak snighda Lakshana. The initial dose was started with Hrisiyasi Matra i.e. $25 \mathrm{ml}$. with lukewarm water as Anupana in early morning, after the digestion of previous night meal. Then patient is advised to continue little quantity of hot water frequently and to avoid Asta Mahadoshakara bhavas. Patient is advised to take rice gruel when feels hunger in the afternoon and during night. After attaining Samyak Snigdha Lakshanas stop the Snehapana.

- Swedana: Dashamoola Qwatha Bashpa Sweda ${ }^{\{6\}}$ was done for 2 days during the Vishrama kala. Swedana was assessed based on Samyak Swinna lakshanas such as Sweda Pradhurbhava, Sheetha vyuparama, Shoola Vyuparama, Sthamba Nigraha, Gaurava Nigraha, Mardavata of Twacha.

- Kaphotkleshakara Ahara on the previous day of Vamana Karma.

\section{Pradhana Karma:}

- Serum electrolytes will be checked prior to $\mathrm{Va}$ mana Karma

- Akantapana with milk.

- The Vamana Yoga of Madanaphala Choorna, Madhu, Saindava Lavana ${ }^{\{7\}}$ is given in quantity sufficient depending upon Rogibala, Rogabala and Koshta.

- Vamanopaga- Yastimadhu phanta: quantity sufficient.

\section{Paschat Karma:}

- Dhumapana with Haridra churna.

- Peyadi Samsarjana krama depending on Shuddhi Lakshana - 3 to 7 days.

- Advised to avoid Asta Mahadoshakara Bhavas.

- Serum electrolytes will be checked after the $\mathrm{Va}$ mana karma.

\section{Results}

Changes observed in the Serum electrolytes leves before and after Vamana karma- Table no:1

\begin{tabular}{|c|c|c|c|c|c|c|c|c|c|c|}
\hline Parameters & Mean & $\mathrm{N}$ & $\begin{array}{l}\text { Std. De- } \\
\text { viation }\end{array}$ & $\begin{array}{l}\text { Std. Er- } \\
\text { ror Mean }\end{array}$ & $\begin{array}{l}\text { Mean } \\
\text { ence }\end{array}$ & differ- & $\%$ & $\mathrm{~T}$ & $\mathrm{P}$ value & Interpretation \\
\hline $\begin{array}{l}\text { Serum } \mathrm{Na}^{+} \\
\text {BT }\end{array}$ & 139.3 & 20 & 3.92 & & 0.87 & \multirow[t]{2}{*}{-0.85} & \multirow[t]{2}{*}{-0.61} & \multirow[t]{2}{*}{-0.962} & \multirow[t]{2}{*}{0.348} & \multirow[t]{2}{*}{ NS } \\
\hline $\begin{array}{l}\text { Serum } \mathrm{Na}^{+} \\
\text {AT }\end{array}$ & $\begin{array}{l}138.4 \\
5\end{array}$ & 20 & 1.75 & & 0.39 & & & & & \\
\hline $\begin{array}{l}\text { Serum } \mathrm{K}^{+} \\
\text {BT }\end{array}$ & 4.01 & 20 & 0.38 & & 0.08 & \multirow[t]{2}{*}{$\begin{array}{l}- \\
0.009\end{array}$} & \multirow[t]{2}{*}{-0.23} & \multirow[t]{2}{*}{-0.155} & \multirow[t]{2}{*}{0.878} & \multirow[t]{2}{*}{ NS } \\
\hline $\begin{array}{ll}\text { Serum } & \mathrm{K}^{+} \\
\text {AT } & \end{array}$ & 4.00 & 20 & 0.45 & & 0.10 & & & & & \\
\hline $\begin{array}{l}\text { Serum } \\
\text { CL- BT }^{-}\end{array}$ & 99.25 & 20 & 2.65 & & 0.59 & \multirow[t]{2}{*}{-0.30} & \multirow[t]{2}{*}{-0.30} & \multirow[t]{2}{*}{-0.471} & \multirow[t]{2}{*}{0.643} & \multirow[t]{2}{*}{ NS } \\
\hline $\begin{array}{l}\text { Serum } \\
\text { CL-AT }\end{array}$ & 98.95 & 20 & 3.15 & & 0.70 & & & & & \\
\hline
\end{tabular}

- The Sr Sodium mean before the treatment was $139.3 \mathrm{mEq} / \mathrm{L}$, after the treatment $138.45 \mathrm{mEq} / \mathrm{L}$ and the mean difference is -0.85 , which is statistically not significant with $\mathrm{p}$ value 0.348 .

- The Sr Potassium mean before the treatment was $4.0150 \mathrm{mEq} / \mathrm{L}$, after the treatment $4.0055 \mathrm{mEq} / \mathrm{L}$ and the mean difference is -0.00950 , which is statistically not significant with $\mathrm{p}$ value 0.878 .

- The Sr Chloride mean before the treatment was $99.25 \mathrm{mEq} / \mathrm{L}$, after the treatment $98.95 \mathrm{mEq} / \mathrm{L}$ and the mean difference is -0.30 . which is statistically not significant with $\mathrm{p}$ value 0.643 . 
Graph 1: Sodium level BT \& AT

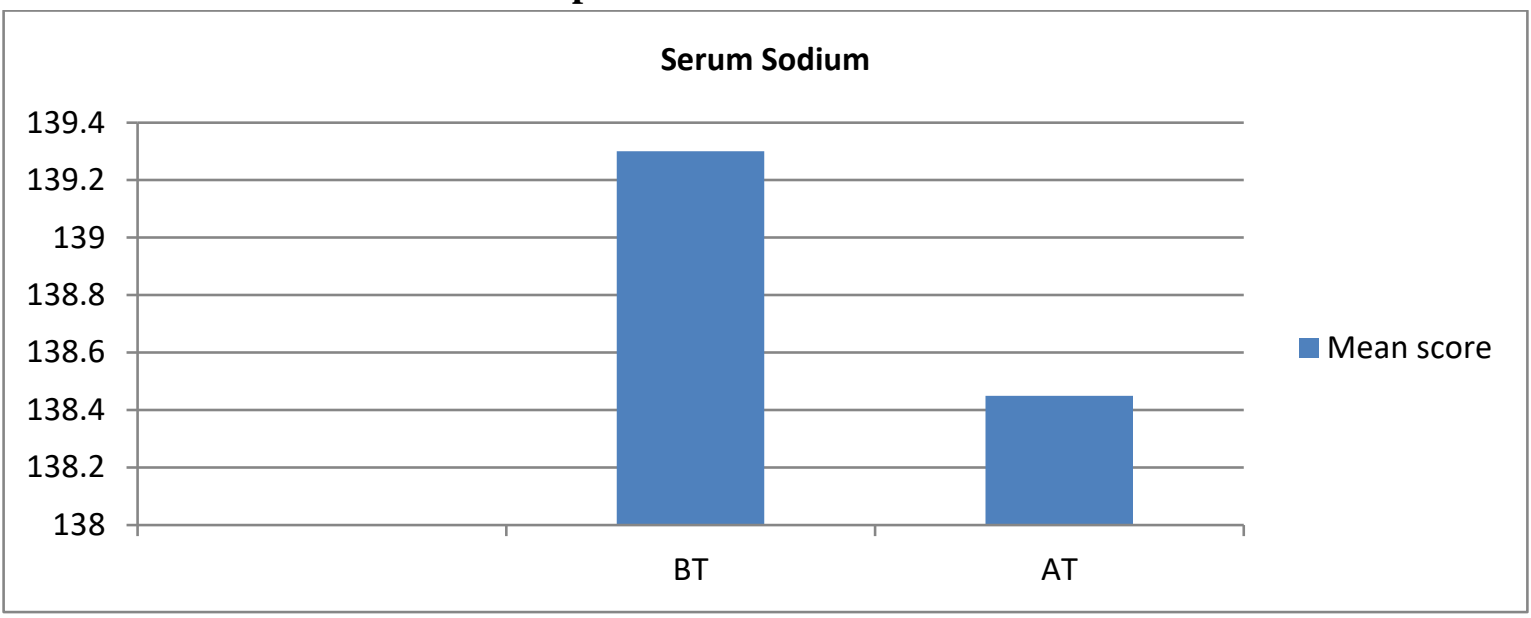

Graph 2: Potassium level BT \& AT

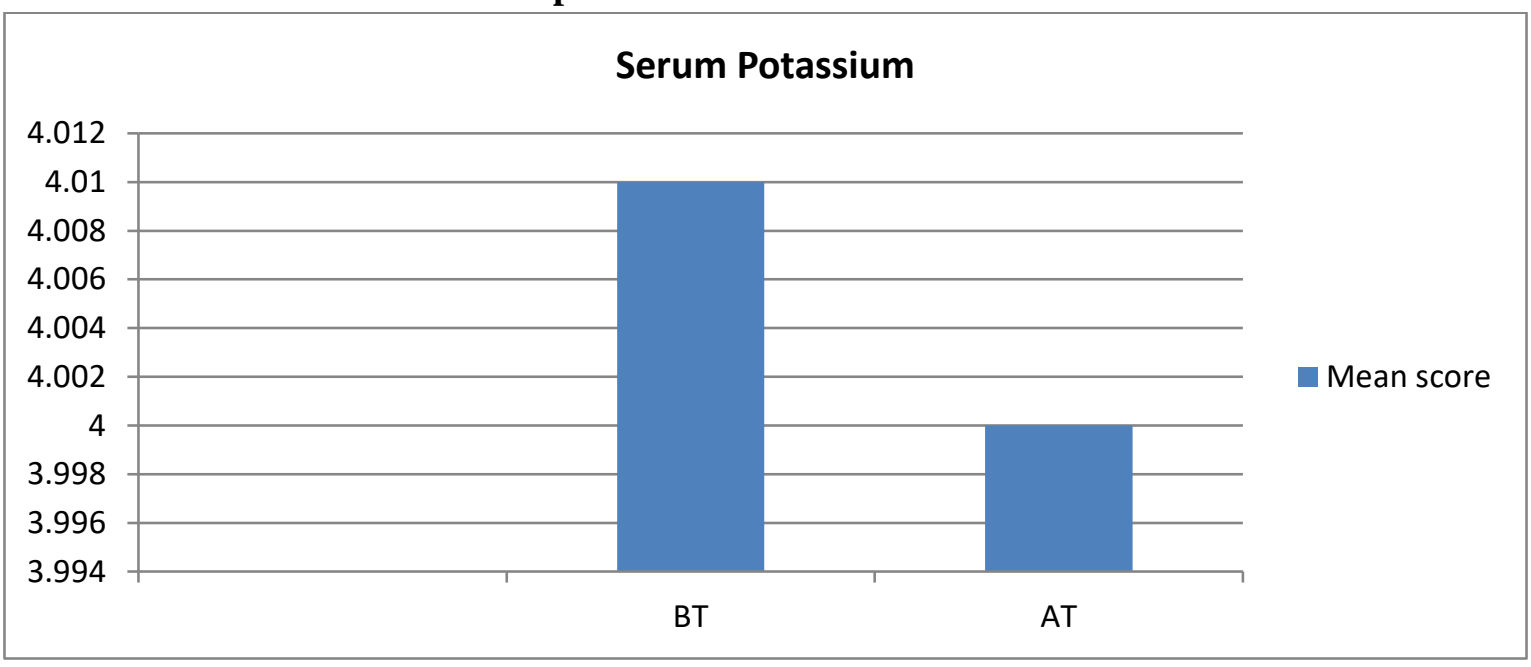

Graph 3: Chloride level BT \& AT

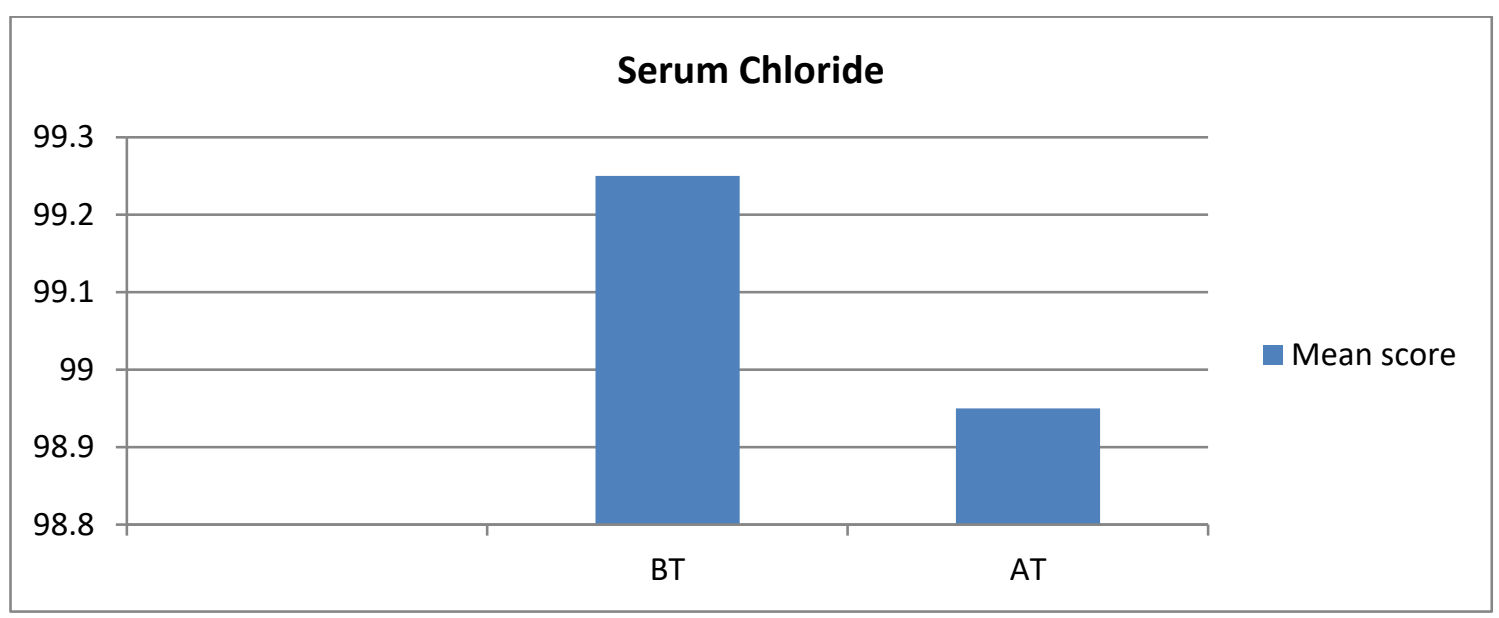




\section{DISCUSSION}

The assessment of Vamana is done on the basis of Vaigiki, Maniki, Laingiki and Anthiki lakshanas. Here the Samyak yoga or Ayoga of Vamana karma is assessed by Laingiki and Anthiki lakshanas. Whereas Vaigiki and Maniki lakshanas are helpful in the assessment of Pravara, Madhyama and Avara shuddhi. These measures also helpful in planning the Samsarjana krama.

Hrita Dosha lakshanas like Karshyatha, Dourbalya, Laghavata seen in Samyak yoga lakshana of Vamana karma $^{\{8\}}$. These features are similar to features of $A p$ dhatu kshaya. But the symptoms here are milder. But if the Atiyoga symptoms like Bhrama, Moorcha, and other Vata prakopa features are observed in the subjects then these symptoms are similar with the features of severe fluid and electrolyte loss. There will be fluid and electrolyte imbalance, if the subject has features of acute gastroenteritis. Even though the subjects are having Samyak lakshanas and number of vegas and output difference during Vamana, will not lead to any such features except some mild symptoms. The reason may be in disease condition vomiting is induced by the organisms, where in Vamana it is induced by the medicine. Apart from this, Poorva karma followed before giving Vamana may have role in preparing the body to face the consequences.

Vamana karma is not simple gastric lavage as done now a days to empty the content of stomach, it is a complete management of systemic diseases caused by Kapha. Urdva amashaya is the seat of Kapha ${ }^{\{9\}}$. The active principle of Vamana drug taken orally is absorbed from the stomach into circulatory system from where it is circulated all over the body. On reaching site of lesion (Dosha sanghata), at the cellular level, it breaks the nexus of Doshas with the Dushya's and bring back the toxic substances thus released into the stomach, from they are expelled out of the body by the action of vomiting.

The modern-day literature suggests that vomiting leads to dehydration, electrolyte imbalance and loss of electrolytes, hypotension, and shock. Certain Vyapada's of Vamana karma and signs and symptoms of excessive Vamana are described in Ayurveda which are similar to the features of dehydration and associated complications. Hence Vamana being therapeutically induced vomiting need to be evaluated for its safety. Thus, the present study was conducted to establish the safety profile of Shodhana karma if conducted as per the classical guidelines starting with Poorvakarma, followed by Pradhana karma and finally completing with Samsarjanakrama. To support this Hypothesis, the electrolyte study was undertaken before and after the treatment, it is clear that the deviation is within normal range. The clinical features of hyponatremia, hypokalemia, hypochloremia was not reported in any of the 20 participants after Vamana karma. Statistically, the results showed not significant change in levels of serum sodium, potassium and chloride levels. As a Poorvakarma person is administered with Snehapana, after attaining Samyak snigdha lakshanas, Swedana done for 2 days. Importance given to Poorvakarma because it helps to bring the Doshas from Shaka to Kosta. There after due to Vamaka aushada prayoga vitiated Doshas expelled out from the body. The present study was conducted to establish the safety profile of Shodhana karma if conducted as per the classical guidelines starting with Poorva karma, followed by Pradhana karma and finally completing with Samsarjana krama.

\section{CONCLUSION}

Amavata is a Vyadhi where Kapha and Vata are predominantly involved. Its Udhbava sthana is Amashaya and Vyaktha Sthana is Sandhi. Vamana is considered as best treatment for Kapha and its associated conditions. In Amavata mainly Kapha sthana like Sandhi is affected. Langhana is considered as the prime line of treatment for Amavata. Vamana is considered under Shodhana variety of Langhana by Charaka. Systemic disease caused by Kapha can be completely managed by Vamana Karma. Urdhwa amashaya is the seat of Kapha dosha. The active principle of Vamana dravyas taken orally are absorbed from the Amashaya into circulatory system from there it is circulated all over the body reaching the site of Dosha sanghata, breaking of Dosha dushya samurchana occurs and harmful substances are release into 
the stomach, from where they are expelled out of the body through Vamana.

The symptoms of Hritadosha are simulating with mild symptoms of AP dhatu kshaya in the body. The AP dhatu kshaya features may be correlated with mild degree of fluid and electrolyte loss.

The present study is aimed to ascertain the safety of Vamana karma, which was performed keeping in mind that the Panchakarma procedure through efficacious and safe needed an assessment of its safe application in this modern era. Serum electrolytes values were well within the normal ranges in all the 20 patients after the therapeutic vomiting. The study was helpful in establishing the safety of therapeutic vomiting, i.e. Vamana karma subjectively and statistically as well without causing any adverse effects. Further scope of the study will be application of other Panchakarma therapies can also be conducted using various parameters.

\section{REFERENCES}

1. Madhavakara, Madhava Nidana, with Madhukosha Commentary, by Dr.P. Himasagara Chandramurthy; Chowkamba Orientalia Varanasi, $1^{\text {st }}$ edition, 2006; Pp375, pg.no:272.

2. Agnivesha, Charaka Samhitha, Acharya Jadavji Trikamji, Choukambha Publication 2001 Varanasi; Pp 738, Pg. No:121.

3. API textbook of medicine. $7^{\text {th }}$ edition 2006 Editor Siddharth. N. Shah. Pp-1533 page.no-1160-1164.

4. Vaidya Jadavji Trikamji, editor. Commentry Ayurveda Dipika of Chakrapanidatta of Charaka Samhitha of Charaka and Dridhabala, Chikitsa Sthana; Grahanidosha chikitsitam: Chapter 15, Verse 17. Varanasi: Chaukhamba prakashan 2010. Pp.738, P.520.

5. Kaviraj Govind Das Sen, Bhaishajya Ratnavali, Siddhiprada Hindi teeka, edited by Prof.Siddhi Nandan Mishra, edition 2011, Varanasi Chaukamba Surabharathi Prakashan, Vol 1, Pp 1196, P. 206.

6. Bhavamishra, Bhavaprakasha, Vidyotini Hindi teeka, edited by Brahmsankar S Mishra and Rupelalaji Vaisey, edition 2010, Varanasi Chowkambha Sanskrit Bhavan, Vol 2, Pp 959, P. 24.

7. Agnivesha. Charaka Samhita. Ayurveda Deepika commentary of Chakrapanidatta, edited by
8. Yadavji Trikamji Acharya, Varanasi: Chowkambha Surabharati Prakashana, 2013.Pp 738, P.14.

9. Agnivesha, Charaka Samhitha, Acharya Jadavji Trikamji, Choukambha Publication 2001 Varanasi; Pp 738, Pg.No:121.

10. Vagbhatacharya, Astanga Hridhaya, Pandit Bhishakacharya Harishastri Paradakara, Chuakambha Orientalia 2006, Varanasi; Pp956, Pg.No:7.

\section{Source of Support: Nil \\ Conflict of Interest: None Declared}

How to cite this URL: Rakshitha Kumari \& Niranjan Rao: A Clinical Study To Evaluate The Impact Of Vamana Karma On Serum Electrolytes In Amavata W.S.R Rhuematoid Arthritis. International Ayurvedic Medical Journal \{online\} 2021 \{cited May, 2021\} Available from: http://www.iamj.in/posts/images/upload/2896_2901.pdf 